\title{
Analisis Perbandingan Velocity Dan Shear Stress Perkembangan Boundary Layer Flat Plate Menggunakan Turbulent Model $k-\varepsilon$ (Standard, Realizable, RNG)
}

\author{
Setyo Hariyadi S.P. ${ }^{1,2}$ \\ ${ }^{1}$ Laboratorium Mekanika dan Mesin Fluida \\ Jurusan Teknik Mesin, Fakultas Teknologi Industri, Institut Teknologi Sepuluh Nopember (ITS) \\ ${ }^{2}$ Akademi Teknik dan Keselamatan Penerbangan Surabaya \\ Kontak Person: \\ Setyo Hariyadi S.P. \\ ${ }^{1}$ Jl. Arief Rahman Hakim, Surabaya 60111 Indonesia \\ ${ }^{2}$ Jemur Anyani I/73 Wonocolo Surabaya 60236 Indonesia Telp. 031-8410871 \\ e-mail: hudzaifahsetyo@gmail.com
}

\begin{abstract}
Abstrak
Pengertian lapisan batas adalah daerah dimana aliran mengalami hambatan karena adanya tegangan geser yang besar pada permukaan benda, sehingga partikel-partikel fluida terpaksa berhenti pada sekitar permukaan benda karena geseran viskos. Aliran fluida sejati mana pun selalu menunjukkan adanya suatu daerah yang alirannya terhambat, yaitu dekat batas yang kecepatannya relatif terhadap batas bervariasi antara nol pada batas hingga suatu harga yang dapat diduga dari solusi aliran potensial di titik yang agak jauh dari situ. Daerah yang alirannya terhambat ini disebut lapisan batas (boundary layer) dan ketebalan lapisan batas itu sendiri dinyatakan dengan $\delta$.Proses pembentukan lapisan batas mungkin poling baik bila divisualisasikan dengan membayangkan aliran di sepanjang sebuah pelat rata. Misalkan ada aliran seragam sebuah fluida tak dapat mampat mendekati pelat dengan kecepatan freestream. Ketika fluida mencapai tepi sebelah depan, tegangan geser yang besar terbentuk dekat dengan permukaan pelat karena partikel-partikel fluida yang tiba di situ terpaksa berhenti dan partikel-partikel yang cukup dekat dan normal terhadap plat dihambat oleh geseran viscous. Lapisan batas menebal dalam arah yang sama dengan arah aliran, akibatnya perubahan kecepatan dari nol di permukaan pelat hingga jarak tertentu pada jarak $\delta$ semakin jauh menjadi semakin besar. Laju perubahan kecepatan tadi menentukan gradient kecepatan di permukaan plat dan karena itu tegangan gesernya juga.

Studi numerik telah dilaksanakan untuk menguji kinerja aerodinamis pada plat datar dengan menggunakan beberapa turbulent model $k-\varepsilon$ (Standard, Realizable, $R N G$ ). Kecepatan freestream yang digunakan yaitu kecepatan $10 \mathrm{~m} / \mathrm{s}$ dan pada kondisi udara standard. Parameter yang dievaluasi meliputi shear stress dan profil kecepatan.

Dari penelitian tersebut didapatkan bahwa dengan penggunaan turbulent model $k-\varepsilon$ Realizable menghasilkan yang terbaik dibandingkan turbulent model yang lain.
\end{abstract}

Kata kunci: lapisan batas,plat datar,efek viscous, turbulent model, $k-\varepsilon$ (Standard, Realizable, RNG)

\section{Pendahuluan}

Pengertian lapisan batas adalah daerah dimana aliran mengalami hambatan karena adanya tegangan geser yang besar pada permukaan benda, sehingga partikel-partikel fluida terpaksa berhenti pada sekitar permukaan benda karena geseran viskos.

Aliran fluida sejati mana pun selalu menunjukkan adanya suatu daerah yang alirannya terhambat, yaitu dekat batas yang kecepatannya relatif terhadap batas bervariasi antara nol pada batas hingga suatu harga yang dapat diduga dari solusi aliran potensial di titik yang agak jauh dari situ. Daerah yang alirannya terhambat ini disebut lapisan batas (boundary layer) dan ketebalan lapisan batas itu sendiri dinyatakan dengan $\delta$.

Proses pembentukan lapisan batas mungkin poling baik bila divisualisasikan dengan membayangkan aliran di sepanjang sebuah pelat rata. Misalkan ada aliran seragam sebuah fluida tak dapat mampat mendekati pelat dengan kecepatan freestream. Ketika fluida mencapai tepi sebelah depan, tegangan geser yang besar terbentuk dekat dengan permukaan pelat karena partikel-partikel fluida yang tiba di situ terpaksa berhenti dan partikel-partikel yang cukup dekat dan normal terhadap plat dihambat oleh geseran viscous. 
Lapisan batas menebal dalam arah yang sama dengan arah aliran, akibatnya perubahan kecepatan dari nol di permukaan pelat hingga us pada jarak $\delta$ semakin jauh menjadi semakin besar. Laju perubahan kecepatan tadi menentukan gradient kecepatan di permukaan plat dan karena itu tegangan gesernya juga.

Pada gambar 1 ditunjukkan proses terbentuknya dan berkembangnya boundary layer untuk fluida incompressible viscous melalui semiinfinite flat plate. Pada awalnya, fluida mengalir dengan distribusi kecepatan yang uniform $(U)$. Ketika melewati permukaan flat plate, aliran fluida tersebut mengalami gesekan sehingga bekerja tegangan geser $\left(\tau_{w}(x)\right)$ pada bidang kontak antara fluida dengan permukaan flat plate. Adanya tegangan geser yang bekerja sepanjang aliran menghasilkan distribusi kecepatan. Distribusi kecepatan dimulai dari titik di permukaan flat plate yang mempunyai kecepatan nol sampai pada kecepatan mendekati harga kecepatan uniform pada jarak $\delta(x)$. Hal ini dikarenakan tegangan geser akan bernilai maksimum pada permukaan flat plate, sedangkan nilai tegangan geser akan berkurang pada titik yang semakin jauh letaknya dari flat plate.

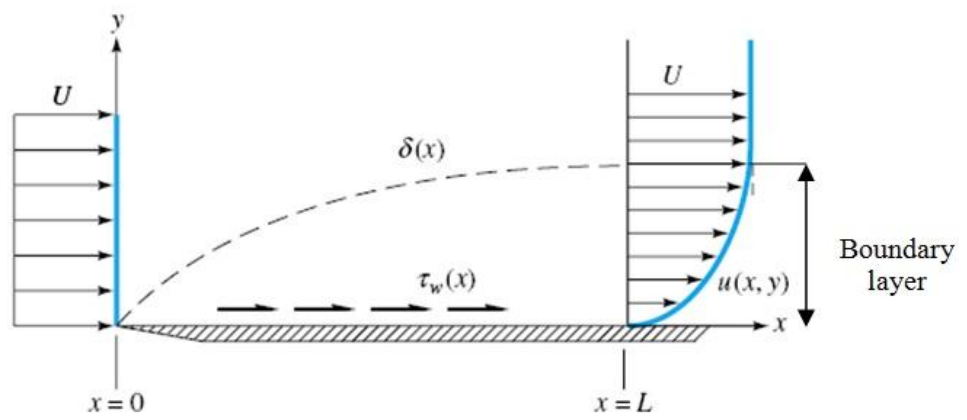

Gambar 1.Boundary Layer pada flat plate untuk aliran incompressible viscous (White, 2001)

Boundary layer dapat dibagi menjadi dua bagian yaitu laminar boundary layer dan turbulent boundary layer. Kedua jenis boundary layer tersebut tergantung pada bilangan Reynolds. Di dalam aliran fluida, proses peralihan dari laminar boundary layer ke turbulent boundary layer disebut sebagai transisi. Lamanya terjadi proses transisi dipengaruhi oleh gradien tekanan, kekasaran permukaan, perpindahan panas, gaya bodi dan gangguan aliran bebas (Fox, et al, 2004).

Proses pembentukan lapisan batas yang mengalami transisi dapat dilihat pada gambar 2. Ketika aliran melintasi plat datar, pada bagian depan partikel-partikel fluida yang cukup dekat terhadap plat dihambat oleh adanya tegangan geser yang besar. Lapisan batas menebal dalam arah yang sama dengan arah aliran. Pada lapisan batas ini terjadi perubahan kecepatan dari nol di permukaan pelat hingga mendekati harga kecepatan free stream pada jarak $\delta$ yang semakin jauh semakin besar. Begitu lapisan batas mulai menebal, ketidakstabilan pun terjadi dan mengakibatkan percampuran partikel (gerak acak) dan perubahan momentum dalam fluida hingga menyebabkan terbentuknya lapisan batas turbulent. Pada lapisan batas turbulen, profil kecepatan yang terbentuk lebih tebal ( full) dengan gradien kecepatan di permukaan plat dan tegangan gesernya lebih tinggi daripada kondisi laminar maupun transisi.

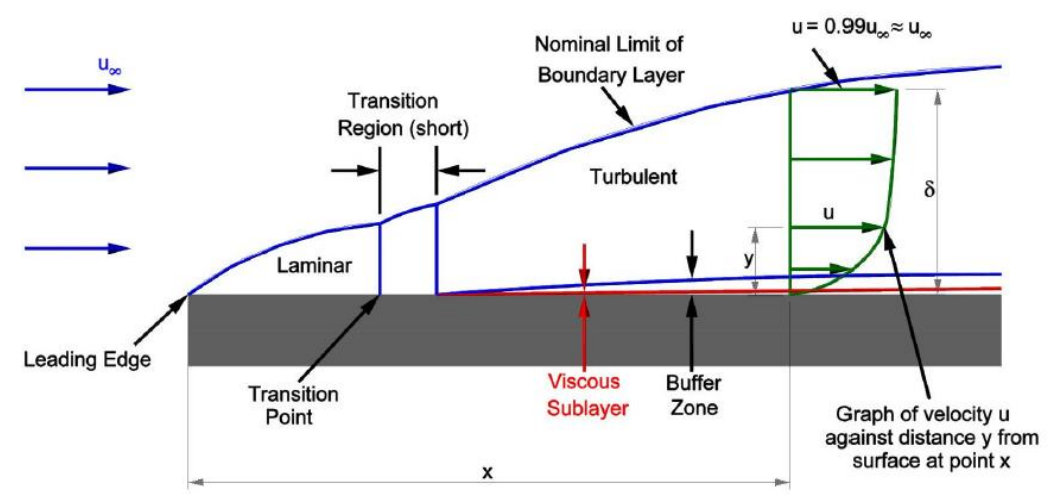

Gambar 2. Aliran fluida di atas permukaan flat plate(Khatri, 2012) 
CFD sangat berguna dalam berbagai variasi aplikasi yang akan digunakan nantinya. Tentu saja aplikasi yang dimaksudkan disini adalah aplikasi tentang aliran fluida pada sebuah tempat/alat atau lainnya. CFD banyak sekali digunakan dalam dunia industry. Sebagai contoh penggunaan CFD di industri adalah digunakan untuk mensimulasikan aliran diatas kendaraan atau bisa saja lebih spesifik dengan digunakannya CFD untuk mengamati interaksi propeler atau rotor dengan aircraftfuselage. Rotor dan propeler dapat direpresentasikan dengan modelling dengan variasi yang kompleks.

CFD singkatan dari Computational Fluid Dynamics sebuah teknik komputasi yang dapat digunakan untuk memprediksi, mensimulasikan dan menganalisa aliran fluida, perpindahan kalor, serta reaksi kimia. CFD menggunakan analisa numeric dengan metoda komputasional dengan menggunakan beberapa persamaan aliran dasar fluida seperti persamaan Navier-Stokes, dan persamaan/hukum kekekalan seperti kekekalan massa dan energi.

Sebagai sebuah ilmu yang baru berkembang, CFD mendapat perhatian khusus dari komunitas internasional seiring dengan perkembangan digital dengan bantuan computer. Perkembangan utama yang dilakukan mencakup dua hal penting. Pertama, bagaimana membuat sebuah model fenomena fluida fisik yang tidak bisa didapat dengan mudah dengan eksperimen, misalnya sistem/keadaan cuaca sebuah kendaraan supersonik luar angkasa. Yang kedua, kemampuan untuk menganalisa sistem yang telah dibuat sehingga dapat mengefektifkan pengeluaran biaya tanpa harus menggunakan prosedur pengujian secara langsung.

Munculnya ide untuk mengembangkan teknik komputasi dengan CFD ini merupakan kemajuan yang sangat berarti dalam perkembangan teknologi. Analisa yang dilakukan melalui sebuah simulasi sebelum prototype dibuat dapat meminimalisasi biaya karena dapat mencegah terjadinya kegagalan produk. Selain itu, dalam hal product development yang dilakukan sebuah perusahaan juga dapat disimulasikan dengan bantuan software berbasis CFD ini sebelum langsung dilakukan proses manufakturnya. Dengan bantuan software berbasis CFD ini juga mempermudah komunikasi antara bagian mekanik dan elektrik dalam perancangan sebuah produk pada perusahaan, dan secara langsung akan menghemat biaya.

Studi numerik telah dilaksanakan untuk menguji kinerja aerodinamis pada plat datar dengan menggunakan beberapa turbulent modelk $-\varepsilon$ (Standard, Realizable, $R N G$ ). Kecepatan freestream yang digunakan yaitu kecepatan $10 \mathrm{~m} / \mathrm{s}$ dan pada kondisi udara standard. Parameter yang dievaluasi meliputi shear stress dan profil kecepatan

\section{Metode Penelitian}

Penelitian ini dilakukan dengan simulasi numerik mengunakan software simulasi dengan model turbulen $k-$ $\varepsilon$ (Standard, Realizable, $R N G$ ). Kecepatan aliran freestream yang akan digunakan sebesar $10 \mathrm{~m} / \mathrm{s}$. Model benda uji berupa plat datar. Gambar 3. merupakan domain simulasi serta kondisi batas yang digunakan dalam simulasi.

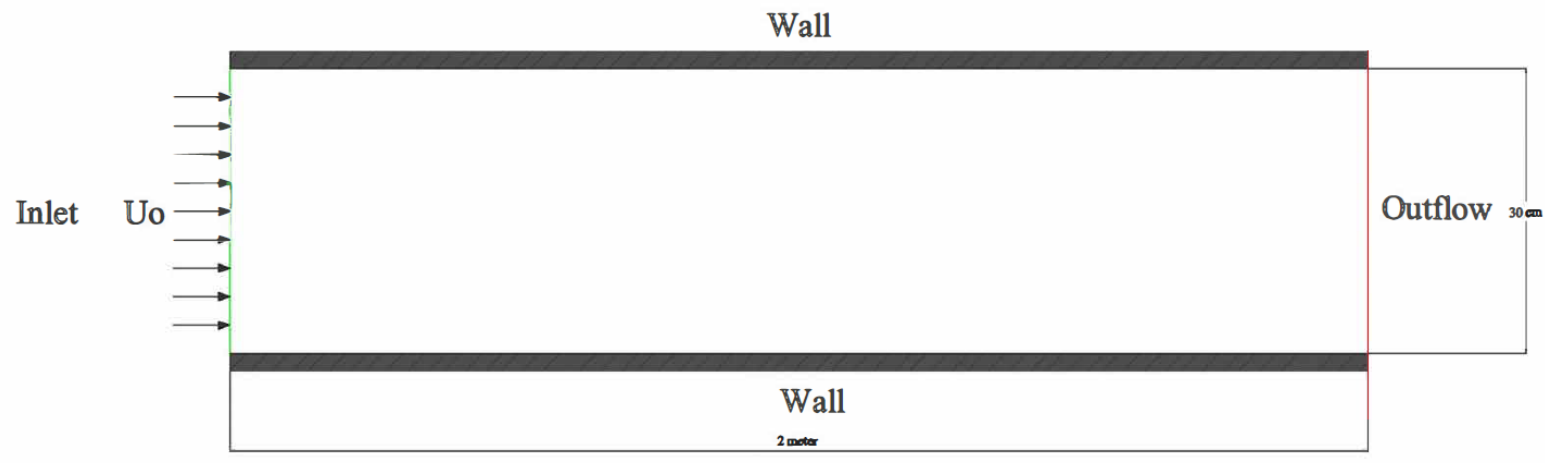

Gambar 3. Meshing dan domain pemodelan airfoil 2D 
Dimensi pemodelan selanjutnya ditunjukkan pada gambar 4.

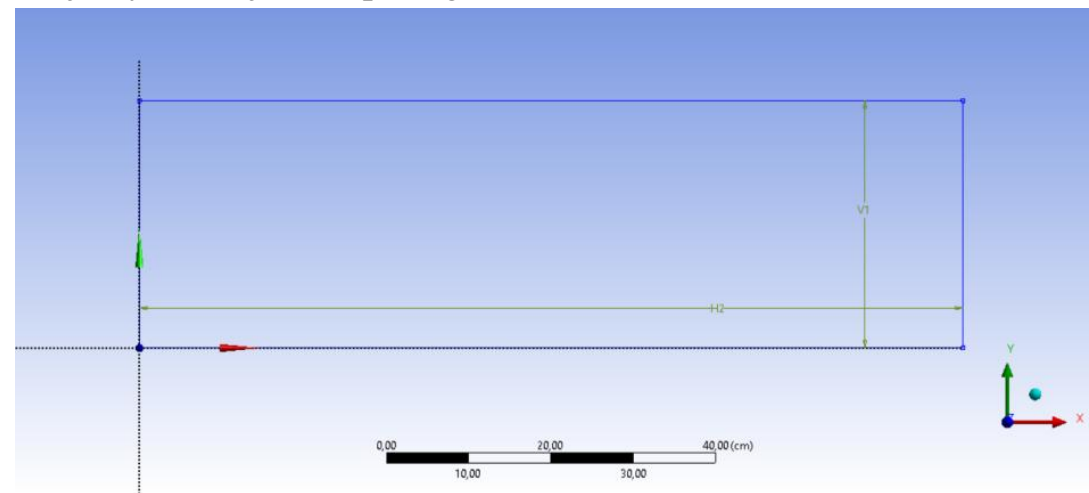

Gambar 4. Dimensi Pemodelan

Pada aplikasi ditentukan analisis 2 dimensi :

$\mathrm{H} 2=200 \mathrm{cmV} 1=30 \mathrm{~cm}$

Setelah ditentukan boundary condition-nya maka selanjutnya meshing yang digunakan adalah quadriateral dan edge sizing di masing-masing sisi boundary condition.

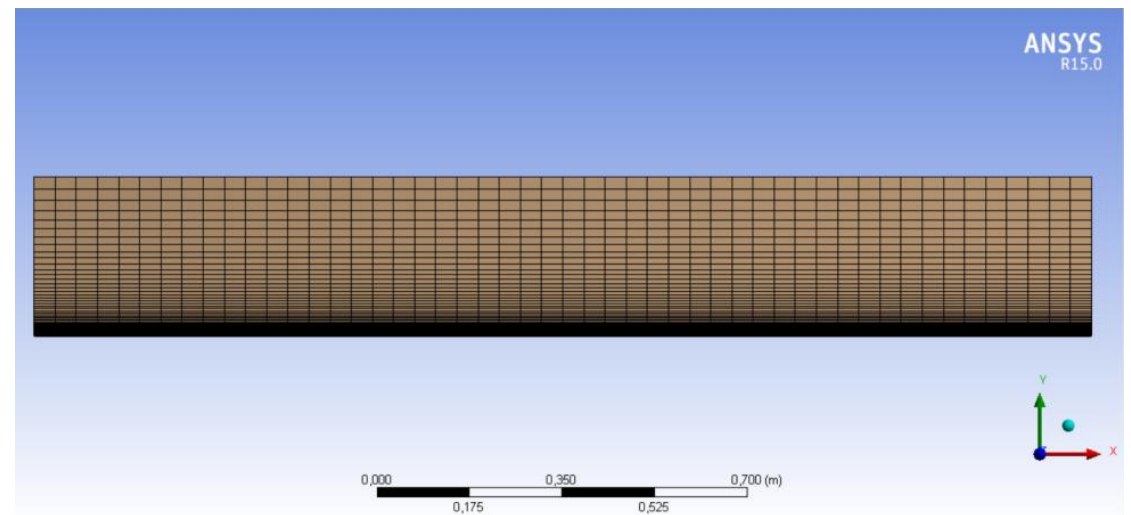

Gambar 5. Meshing yang dihasilkan

Kondisi batas yang digunakan pada penelitian ini antara lain inlet : velocity inlet; outlet : outflow, dinding : wall. Aliran yang digunakan disini berupa aliran inkompresibel. Velocity inlet untuk mendefinisikan kecepatan aliran yang masuk. Kondisi batas outflow dipilih karena data aliran saat kondisi keluar tidak diketahui. Wall didefinisikan sebagai dinding dari aliran fluida yang terdapat di dalam saluran untuk membatasi fluida yang melintas.

Dalam penggunaan software simulasi memerlukan keakuratan data baik pada langkah post processing maupun preprocessingnya. Langkah grid independensi diperlukan untuk menentukan tingkat serta struktur grid terbaik dan terefisien agar hasil pemodelan mendekati sebenarnya. Pada penelitian ini membandingkan juga beberapa kerapatan meshing sebagaimana tampak pada tabel 1.

Tabel 1. Penentuan meshing dan minimal inflation

\begin{tabular}{|c|c|c|c|}
\hline No & Jumlah Node/Grid & $\mathrm{Y}^{+}$ & Minimal Inflation \\
\hline 1 & 4141 & 14 & 0.0005 \\
\hline 2 & 6161 & 6.6 & 0.00025 \\
\hline 3 & 8181 & 4 & 0.00015 \\
\hline 4 & 19701 & 0.98 & 0.000035 \\
\hline
\end{tabular}

Reynolds Number yang digunakan adalah 12,52 x $10^{5}$ sehingga aliran sudah mencapai turbulent. 


\section{Hasil dan Pembahasan}

\section{Velocity Magnitude}

Aliran yang datang melewati sebuah plat datar akan selalu diawali dengan terbentuknya aliran laminar. Sejalan dengan pertumbuhan boundary layer maka aliran tersebut menuju transisi aliran, hal ini dinyatakan dengan bilangan Reynolds untuk aliran ekternal. Apabila nilaiReynolds tersebut melebihi $5 \times 10^{5}$ maka aliran dinyatakan sebagai aliran turbulent.

Gambar 6 menunjukkan kontur velocity magnitude dari inlet sampai dengan $\mathrm{x}=100 \mathrm{~cm}$ sedangkan gambar 7 menunjukkan perbesaran gambar kontur velocity magnitude pada sisi inlet dan $\mathrm{x}=0,276$. Perbedaan warna menunjukkan perbedaan nilai dari velocity. Kontur velocity magnitude menunjukkan bahwa boundary layer thickness berkembang terus menerus ketika melintasi permukaan plate dari sisi inlet sampai dengan outlet. Hal ini sesuai dengan perkembangan aliran dari laminar, transisi dan turbulen sebagaimana ditunjukkan pada gambar 6. Hal ini penting untuk ditunjukkan karena masing-masing boundary layer thickness-nya berbeda. Dimungkinkan aliran yang sudah mendekati $\mathrm{x}=0,27$ mengalami transisi dari laminar ke turbulen karena perubahan boundary layer thickness-nya sudah tidak begitu signifikan.

Pada gambar 6 dan 7 tampak bahwa di luar boundary layer region tidak terpengaruh efek viscous.

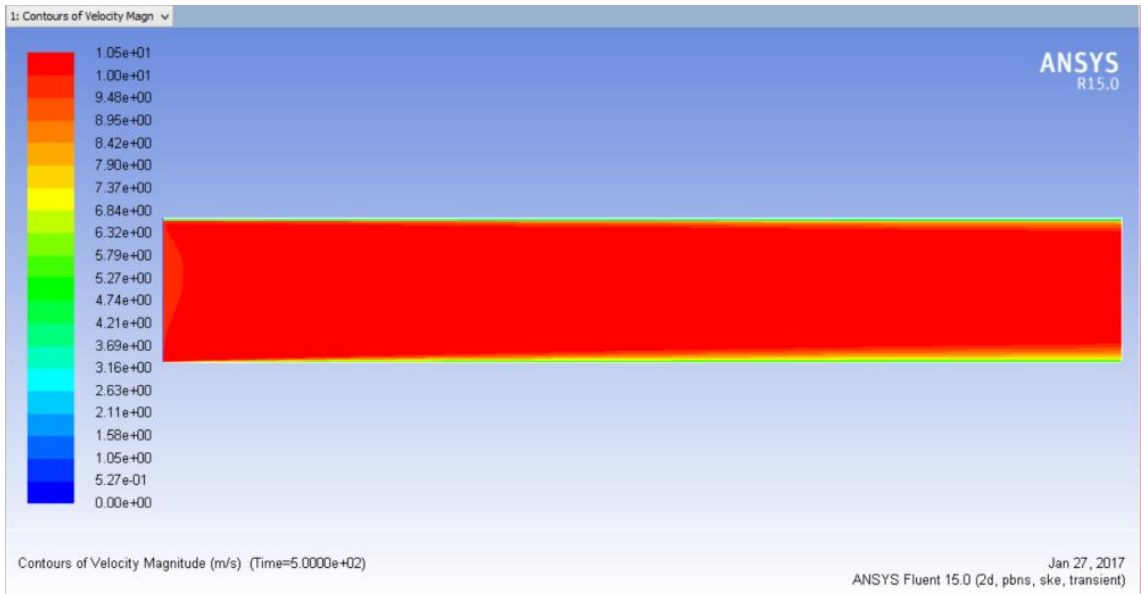

Gambar 6. Kontur Velocity Magnitude (Hasil Ansys Fluent 15)
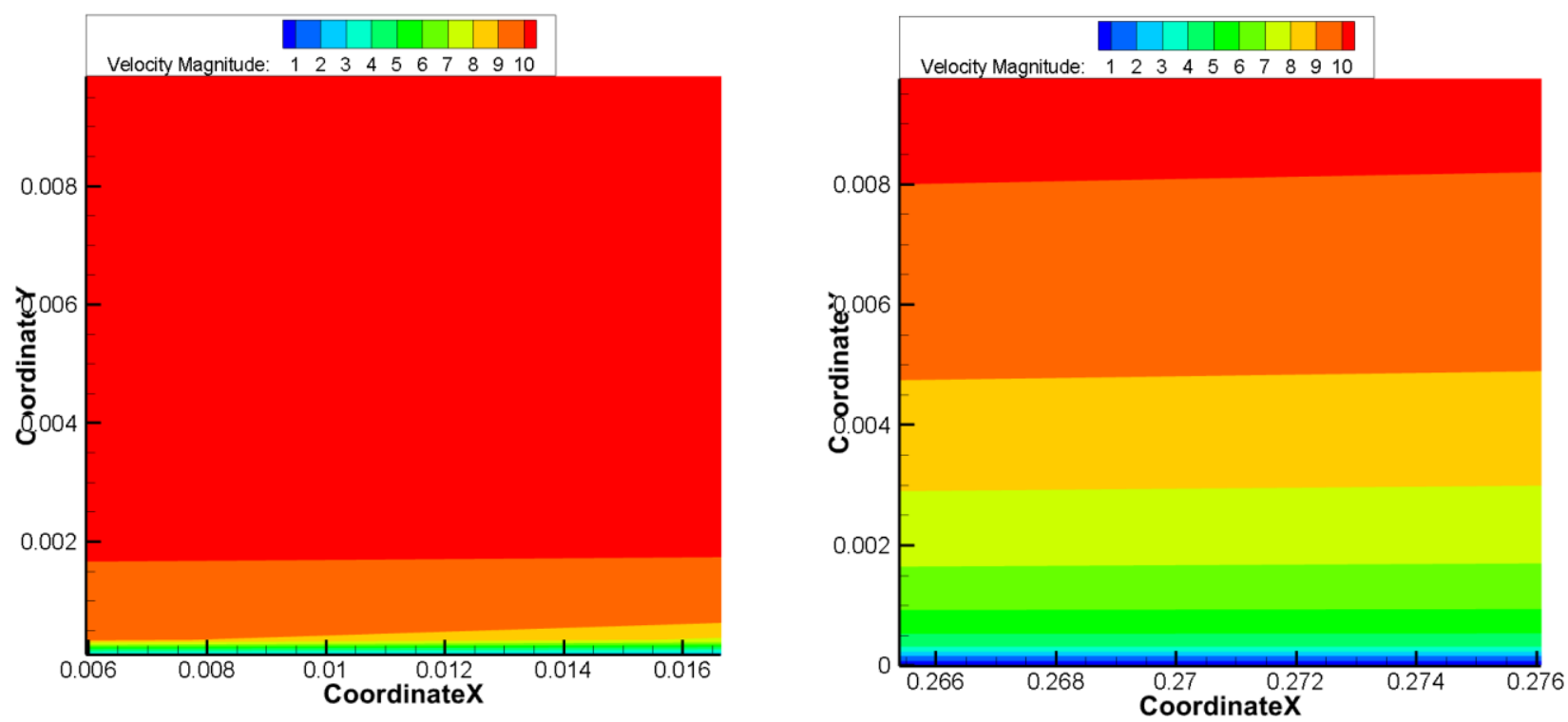

Gambar 7. Kontur Velocity Magnitude (Diperbesar) di depan sisi Inlet dan Outlet (Hasil Techplot 360) 
Gambar 8. menunjukkan profil kecepatan dari simulasi numerik yang diplot sepanjang pelat datar. Gambar 9 merupakan velocity profile di sisi inlet dan gambar 10 merupakan velocity profile pada sisi outlet. Velocity profile yang terbentuk menunjukkan momentum dari aliran masih dapat mengatasi gaya gesek sepanjang permukaan plate. Di sekitar $\mathrm{x}=100 \mathrm{~cm}$ ditunjukkan bahwa aliran belum mengalami separasi. Dari velocity profile yang terbentuk juga menunjukkan bahwa boundary layer terbentuk dengan lambat sampai dengan $\mathrm{x}=100 \mathrm{~cm}$. Pada sisi outletsebagaimana terlihat pada gambar 11belum tercapai fully developed karena profil kecepatan masih mengalami perubahan meskipun sangat sedikit dan terus menerus sampai dengan sisi outlet.

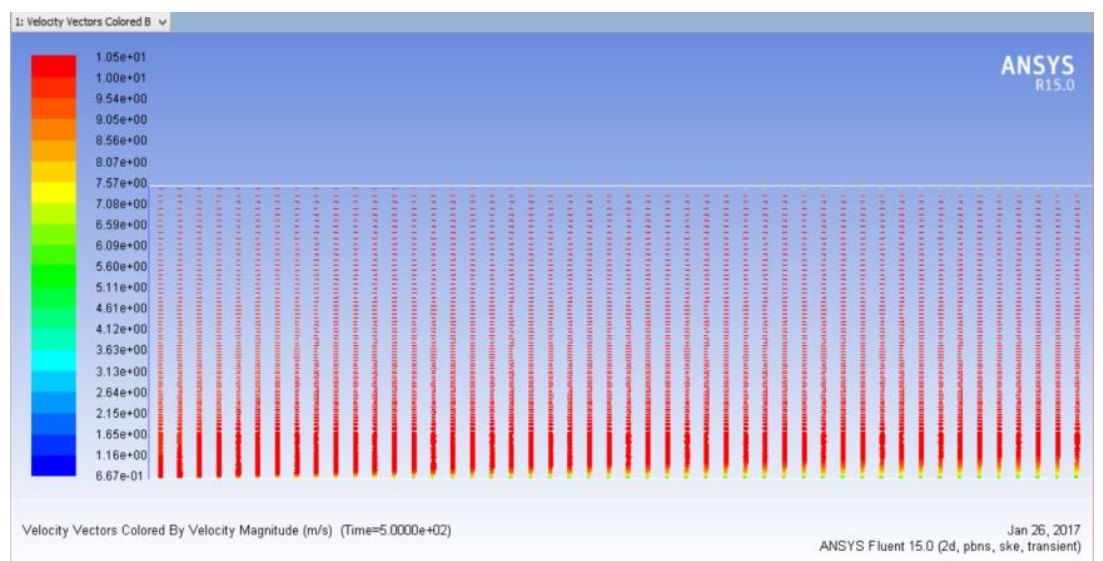

Gambar 8. Velocity Vector (Hasil Ansys Fluent 15)

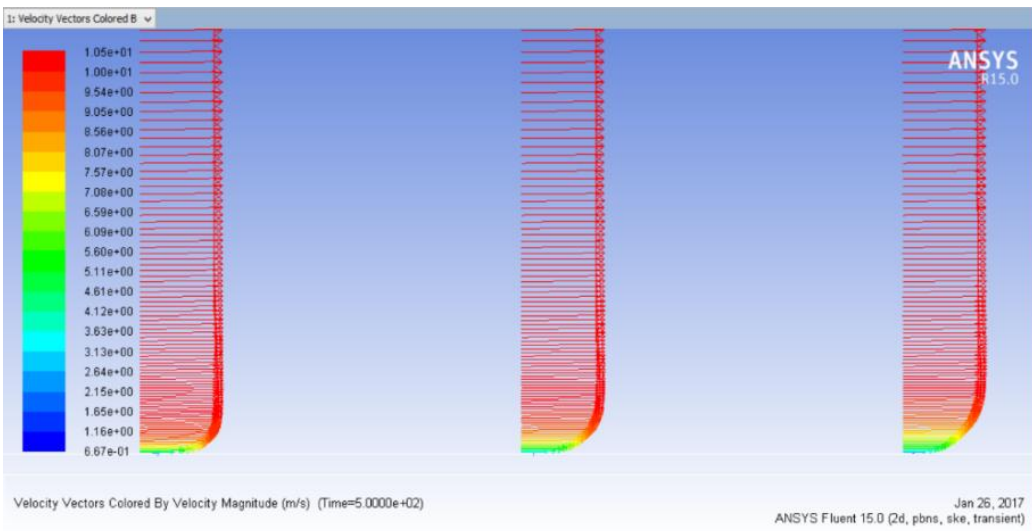

Gambar 9. Velocity Vector (Diperbesar) sedikit di depan Inlet (Hasil Ansys Fluent 15)

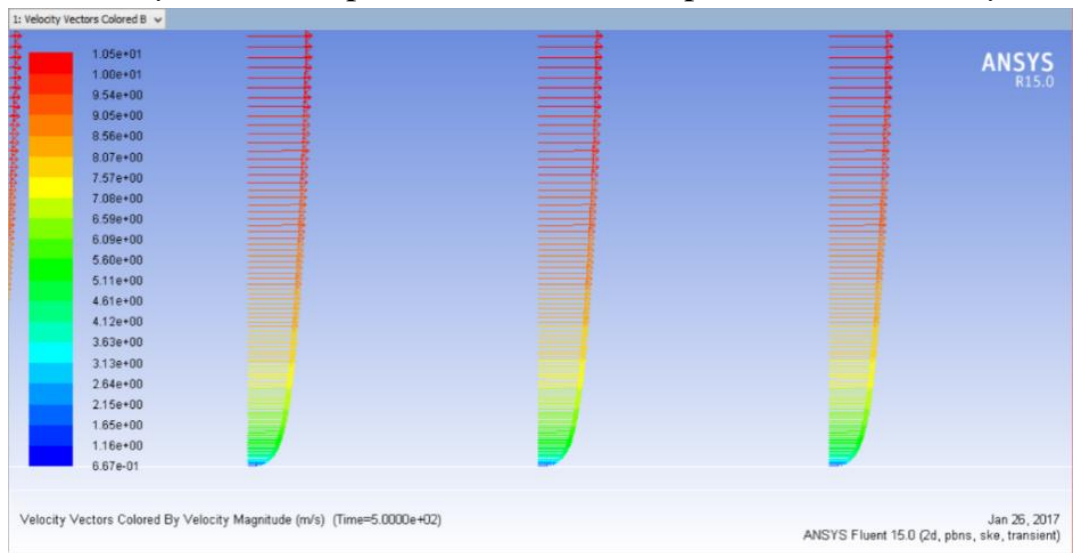

Gambar 10. Velocity Vector (Diperbesar) sekitar $\mathrm{x}=100 \mathrm{~cm}$ (Hasil Ansys Fluent 15) 


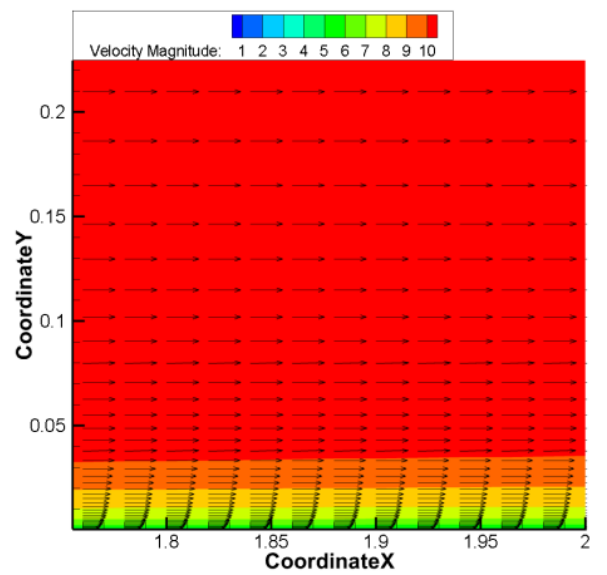

Gambar 11. Velocity Vector (Diperbesar) di sekitar outlet (Hasil Techplot 360)

\section{Shear Stress}

Hubungan antara tegangan geser dan viskositas dan perubahan kecepatan dapat dipahami pada kasus aliran diantara dua plat datar. Misalkan jarak antar plat adalah y dan diantara plat tersebut terdapat fluida dengan isi yang homogen. Asumsikan bahwa plat sangat luas. Dengan luas A yang besar, pengaruh sisi dapat dianggap tidak ada. Pada plat bagian bawah dianggap tetap lalu diberikan gaya sebesar F pada plat atas. Bila ternyata gaya ini menyebabkan material diantara dua plat bergerak dengan perubahan kecepatan u, gaya yang diberikan proposional dengan luas dan perubahan kecepatan.

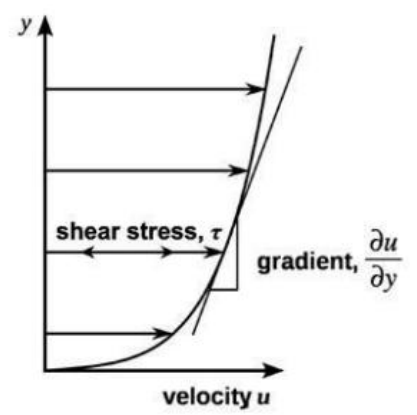

Gambar 12. Perubahan bentuk akibat dari penerapan tegangan geser

Gaya yang diberikan sebanding dengan luas dan gradien kecepatan dalam fluida:

$$
F=\mu A \frac{\vartheta u}{\vartheta y}
$$

Persamaan ini dapat dinyatakan dalam tegangan geser $\tau=\frac{F}{A}$ sehingga :

dimana;

$$
\tau=\mu \frac{\vartheta u}{\vartheta y}
$$

$\tau=$ tegangan geser $\left(\mathrm{N} / \mathrm{m}^{2}\right)$

$\mu=$ viskositas dinamik (N.s $\left./ \mathrm{m}^{2}\right)$

$\mathrm{A}=$ luas penampang lempeng $\left(\mathrm{m}^{2}\right)$

$\delta \mathrm{u} / \delta \mathrm{y}=$ gradien kecepatan $\left(\mathrm{s}^{-1}\right)$

Namun untuk aliran turbulen berlaku :

$$
\tau=\mu \frac{\vartheta u}{\vartheta y}-\rho \overline{u^{\prime} v^{\prime}}=\tau_{\text {lam }}+\tau_{\text {turb }}
$$


Dimana $\rho \overline{u^{\prime} v^{\prime}}$ adalah tegangan Reynolds (Reynolds Stress). Pada aliran laminar $u$ ' dan v' adalah 0. Sehingga $\overline{u^{\prime} v^{\prime}}=0$. Untuk aliran turbulen didapati bahwa $\rho \overline{u^{\prime} v^{\prime}}$ adalah positif sehingga tegangan geser lebih besar terjadi pada aliran turbulen dibandingkan pada aliran laminar. Terlihat pada persamaan di atas bahwa tegangan geser di dalam aliran turbulen tidak semata-mata sebanding dengan garadien kecepatan rata-rata menurut waktu namun tegangan geser tersebut juga mengandung kontribusi fluktuasi acak komponen-komponen $\mathrm{x}$ dan $\mathrm{y}$ dari kecepatan. (Munson, 2009).

Meskipun besaran relatif dari $\tau_{\text {lam }}$ dibandingkan $\tau_{\text {turb }}$ merupakan fungsi kompleks yang tergantung pada aliran tertentu yang terlibat hasil simulasi menunjukkan sebagaimana gambar 13. Di daerah daerah yang sangat sempit di dekat dinding (viscous sublayer), tegangan geser laminar mendominasi. Menjauh dari dinding, porsi turbulen dari tegangan geser mendominasi. Transisi antara kedua daerah ini terjadi pada overlap layer.

Pada gambar 14, gambar 15, dan gambar 16 ditampilkan perbandingan hasil simulasi tegangan geser sepanjang plat datar beberapa turbulence model dengan $\mathrm{y}^{+}$yang berbeda. Didapatkan bahwa semakin baik nilai $\mathrm{y}^{+}$maka akan mendapatkan hasil yang lebih baik. Semakin rapat meshing di sekitar wall akan meningkatkan sensitivitas simulasi ketika iterasi dilakukan. Dengan nilai $\mathrm{y}^{+} \leq 1$ akan mendapatkan hasil yang terbaik meskipun menggunakan turbulence model yang berbeda baik $k-\varepsilon$ Standard, $k-\varepsilon$ RNG maupun $k-\varepsilon$ Realizable.

Pada gambar 17, gambar 18, gambar 18, dan gambar 19 ditampilkan perbandingan hasil simulasi tegangan geser sepanjang plat datar dengan $\mathrm{y}^{+}$yang sama pada turbulence model yang berbeda. Didapatkan bahwa $k-\varepsilon$ Realizable mendapatkan hasil yang lebih baik disusul $k-\varepsilon$ RNG dan $k-\varepsilon$ Standard. $k-\varepsilon$ Realizable mampu mengukur tegangan geser yang lebih sensitif dibandingkan $k-\varepsilon$ RNG dan $k-\varepsilon$ Standard. Hal ini sesuai dengan hasil penelitian Mulvany (2004) bahwa $k-\varepsilon$ Realizable mendapatkan hasil yang lebih baik dibandingkan $k-$ $\varepsilon$ RNG dan $k-\varepsilon$ Standard

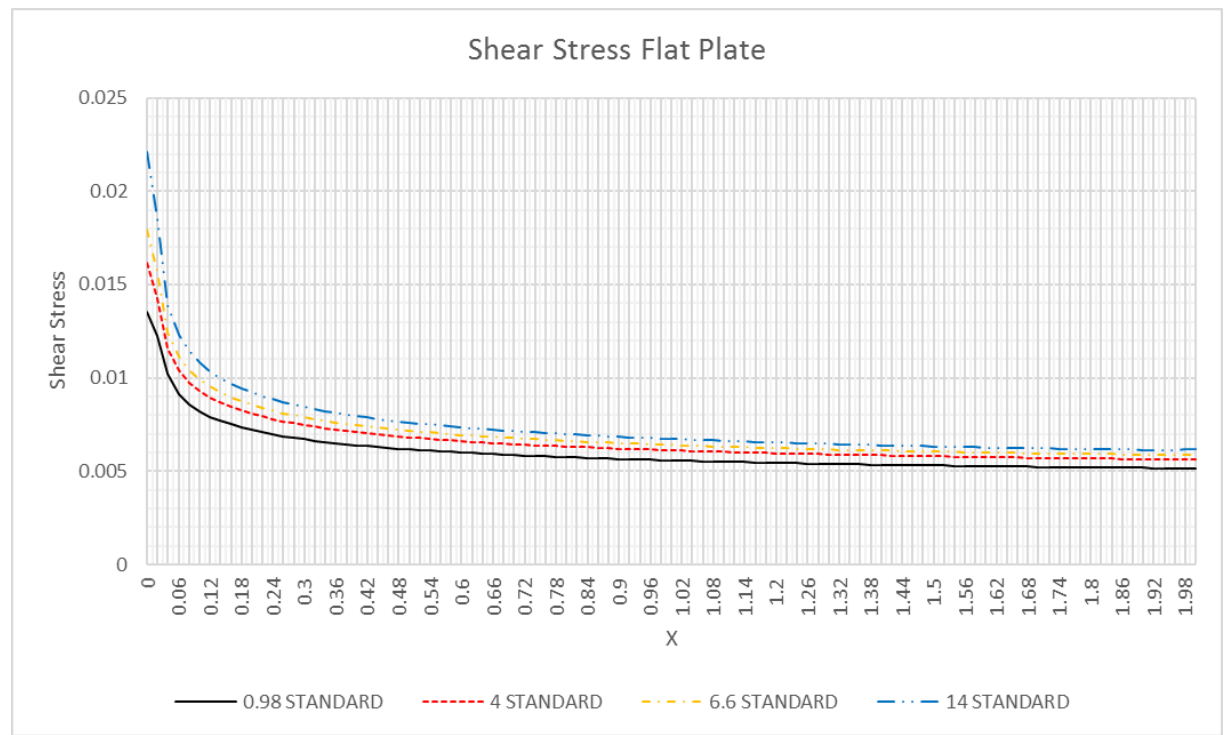

Gambar 14. Tegangan geser pada flat plate hasil simulasi $k-\varepsilon$ Standard dengan $\mathrm{y}^{+}$yang berbeda 


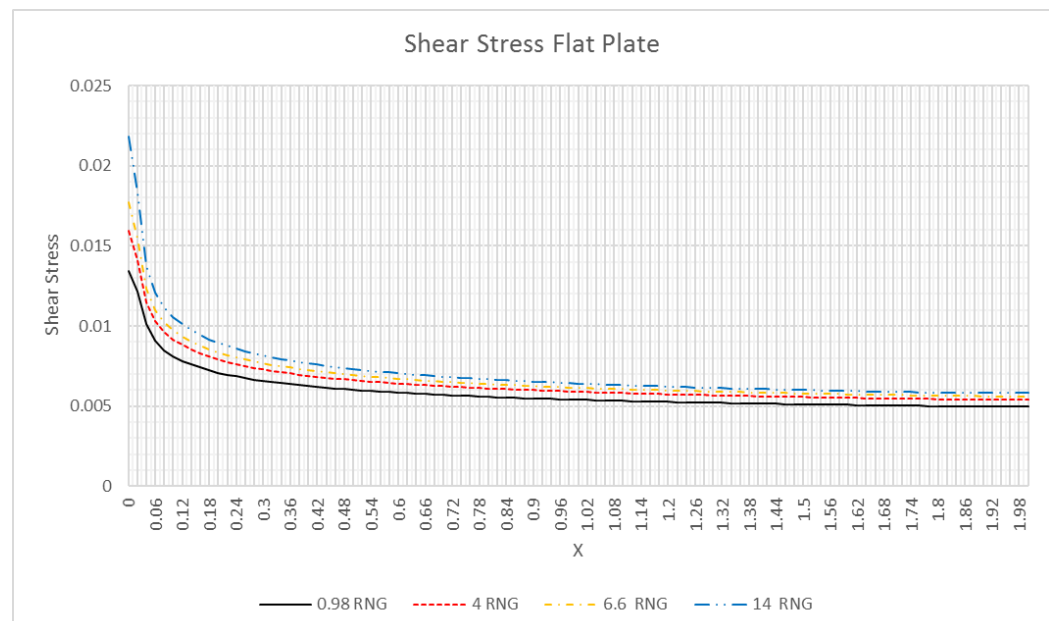

Gambar 15. Tegangan geser pada flat plate hasil simulasi $k-\varepsilon R N G$ dengan $\mathrm{y}^{+}$yang berbeda

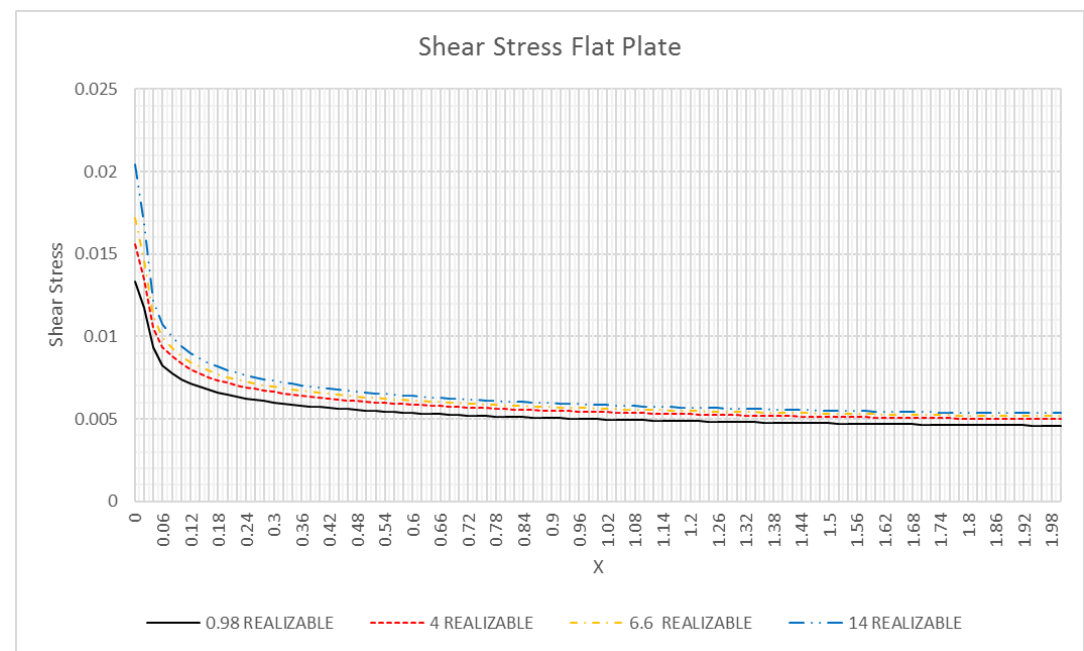

Gambar 16. Tegangan geser pada flat plate hasil simulasi $k-\varepsilon$ Realizable dengan $\mathrm{y}^{+}$yang berbeda

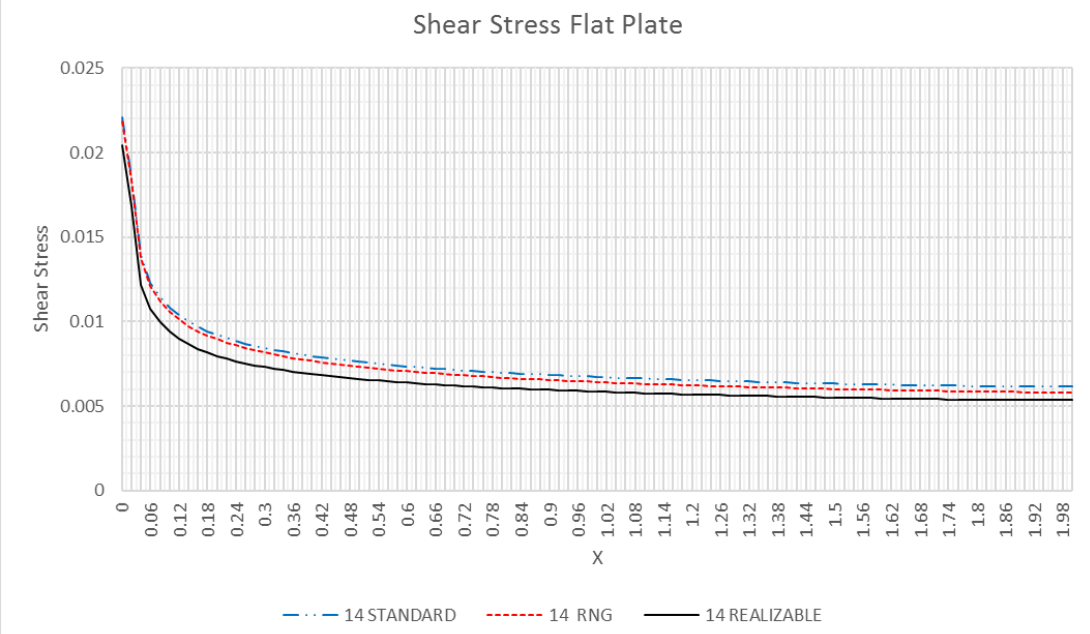

Gambar 17. Tegangan geser pada flat plate hasil simulasi pada $\mathrm{y}^{+} \leq 30$ dengan turbulence model yang berbeda 


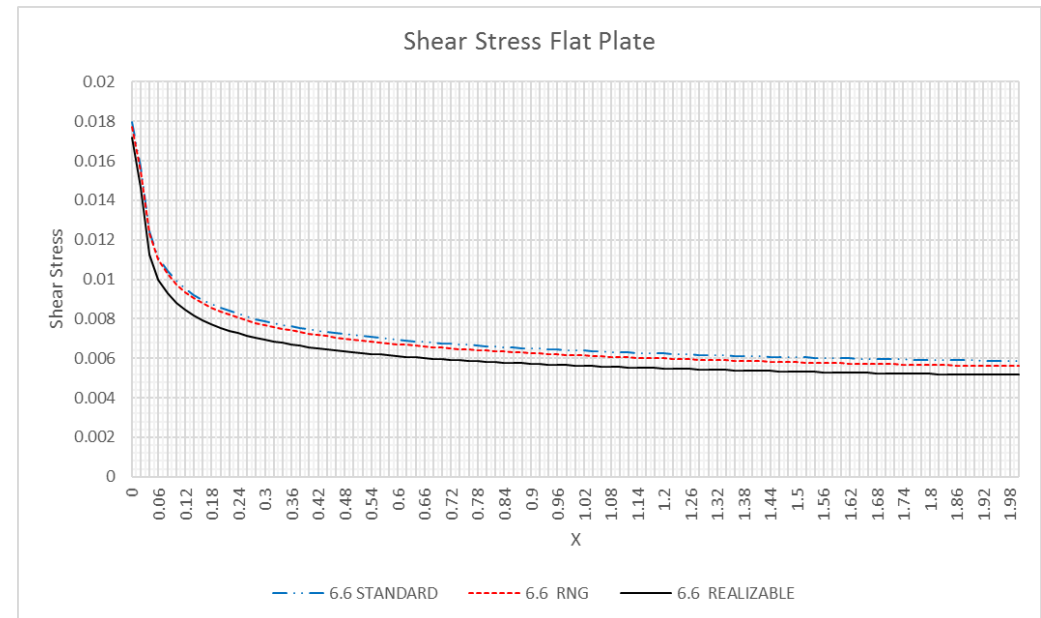

Gambar 18. Tegangan geser pada flat plate hasil simulasi pada $\mathrm{y}^{+} \leq 10$ dengan turbulence model yang berbeda

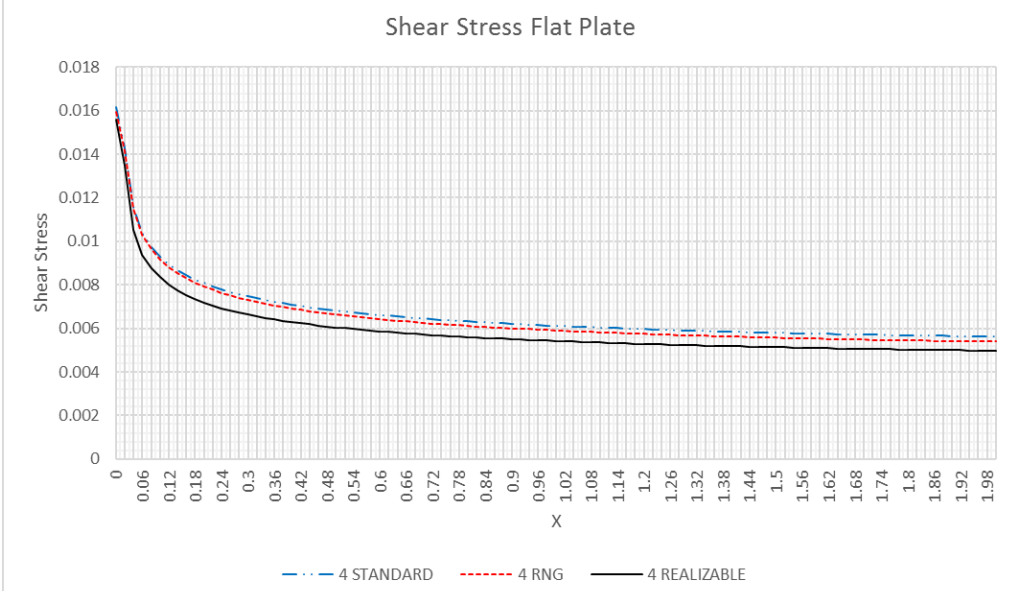

Gambar 19. Tegangan geser pada flat plate hasil simulasi pada $\mathrm{y}^{+} \leq 5$ dengan turbulence model yang berbeda

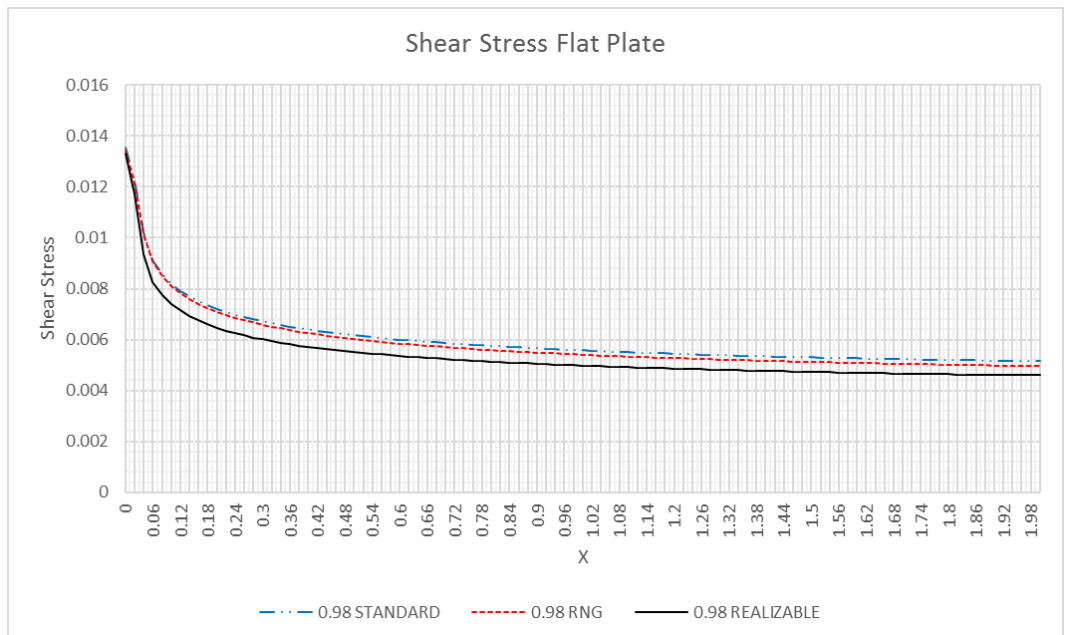

Gambar 20. Tegangan geser pada flat plate hasil simulasi pada $\mathrm{y}^{+} \leq 1$ dengan turbulence model yang berbeda

\section{Kesimpulan}

Penggunaan Computational Fluid Dynamic (CFD) telah dilaksanakan pada penelitian ini. Hasil penelitian ini memperlihatkan bahwa $k-\varepsilon$ Realizable mendapatkan hasil yang lebih baik disusul $k-\varepsilon$ RNG dan $k-\varepsilon$ Standard. $k-\varepsilon$ Realizable mampu mengukur tegangan geser yang lebih sensitif dibandingkan $k-\varepsilon$ RNG dan $k-\varepsilon$ 
Standard. Hal ini sesuai dengan hasil penelitian Mulvany (2004) bahwa $k-\varepsilon$ Realizable mendapatkan hasil yang lebih baik dibandingkan $k-\varepsilon$ RNG dan $k-\varepsilon$ Standard. Dari velocity profile yang terbentuk juga menunjukkan bahwa boundary layer terbentuk dengan lambat sampai dengan $\mathrm{x}=100 \mathrm{~cm}$. Pada sisi outlet belum tercapai fully developed karena profil kecepatan masih mengalami perubahan meskipun sangat sedikit dan terus menerus sampai dengan sisi outlet.

\section{Referensi}

[1]. Fluent Inch (2005), Flow Over Cylinder, Flow Lab 1.2.

[2]. Fox, Robert W., Mc Donald, Alan T., and Pritchard, Philip J. (2004), Introduction to Fluid Mechanics, 6th edition, John Wiley and Sons, New York.

[3]. Khatri, Rajesh, Pankaj Agrawal, Mohan Gupta, Jitendra Verma(2012),Laminar Flow Analysis Over A Flat Plate By Computational Fluid Dynamics, International Journal of Advances in Engineering \& Technology.

[4]. Mulvany, Nicholas J., Li Chen, Jiyuan Y. Tu, Brendon Anderson (2004), Steady State Evaluation of Two Equation RANS Turbulence Models for High Reynolds Number Hydrodynamic Flow Simulations, Final Report, Defence Science and Technology Organisation, Departement of Defence, Australian Goverment 